\title{
A CLINICAL STUDY OF ANALYSIS OF CYSTIC SWELLINGS OF THE SCROTUM
}

\author{
C. Srinivasan 1 , P. Pandian'2, M. Kiran Kumar', M. Ramula 4 , M. Vijayanand 5 \\ 1 Professor, Department of Surgery, Chengalpattu Medical College Hospital. \\ ${ }^{2}$ Assistant Professor, Department of Surgery, Chengalpattu Medical College Hospital. \\ ${ }^{3}$ Assistant Professor, Department of Surgery, Chengalpattu Medical College Hospital. \\ ${ }^{4}$ Associate Professor, Department of Surgery, Chengalpattu Medical College Hospital. \\ 5Junior Resident, Department of Surgery, Chengalpattu Medical College Hospital.
}

\section{ABSTRACT}

\section{BACKGROUND}

The objective of this study is to study various types of clinical presentation of cystic swelling of scrotum and different treatment modalities adopted and their outcome.

\section{MATERIALS AND METHODS}

Between April 2014 and April 2016, 100 patients with cystic swelling of scrotum who got admitted in Surgical Unit of Chengalpattu Medical College and Govt. Hospital, Chengalpattu, were taken up for study and various surgical techniques like eversion, plication, subtotal/partial excision and eversion of sac was adopted.

\section{RESULTS}

Primary vaginal hydrocele (57\%) is the commonest cause of cystic swelling of scrotum followed by congenital hydrocele (14\%) and epididymal cyst (11\%); incidence was more in age group of 31 - 40 years (22\%); most of them were ryots by occupation (30\%); side wise, on right side the incidence was higher. Haematoma and infection was seen in cases where eversion and partial/subtotal excision of sac was done. In Lord's procedure none of them developed haematoma or infection, flattening of testis was seen in 9 cases of primary vaginal hydrocele.

\section{CONCLUSION}

Lord's Plication for hydrocele is simple, effective, safe and economical; in eversion of sac and partial/subtotal excision and eversion of sac haematoma formation and infection is common; but still it is the choice of operation for large hydrocele and in thickened sac.

\section{KEYWORDS}

Lord's Plication, Eversion, Excision of SAC, Congenital Hydrocele, Primary Vaginal Hydrocele.

HOW TO CITE THIS ARTICLE: Srinivasan C, Pandian P, Kumar MK, et al. A clinical study of analysis of cystic swellings of the scrotum. J. Evolution Med. Dent. Sci. 2016;5(100):7374-7380, DOI: 10.14260/jemds/2016/1669

\section{BACKGROUND}

Cystic swellings of scrotum are one of the commonest clinical entities, which surgeon comes across in daily practice.

There are various reasons for scrotum to become swollen ranging from hydrocele the commonest cause, to some rare causes like malignant tumours of the epididymis.

Cystic swellings of scrotum are usually painless and can attain a very big size without causing much discomfort to patient. The scrotum is liable to traumatic injury due to their hanging down position and mobility leading on to haematocele.

Primary hydrocele is an abnormal collection of serous fluids in some part of the processus. Vaginalis, usually the tunica. ${ }^{1}$ Epididymal cysts represents cystic degeneration of the epididymis and are filled with crystal clear fluid. ${ }^{2}$

Spermatocele is a retention cyst arising from either the vasa efferentia of the testis or from the epididymis. ${ }^{3}$ The gold standard of treatment continues to be surgical. ${ }^{4}$

Financial or Other, Competing Interest: None.

Submission 24-11-2016, Peer Review 07-12-2016,

Acceptance 09-12-2016, Published 15-12-2016.

Corresponding Author:

Dr. M. Ramula,

A-14, Old GST Road,

Alagesan Nagar,

Chengalpattu-603001.

E-mail: ramuladurai@gmail.com

DOI: $10.14260 /$ jemds/2016/1669
Cystic swellings of scrotum are a common entity in day to day clinics. Because of varied aetiology, their mode of presentation and management is unique for each. There is a necessity to study the ideal treatment modality for a given type of cystic swelling.

\section{Aims and Objectives of Study}

- To study the different clinical pattern of presentation of patients with cystic swellings of scrotum and their incidence.

- To study the age wise and side wise distribution of the cystic swelling of scrotum.

- These scrotal swellings occur in all age groups. Hence, there is a necessity to study the age wise distribution and the cause and predisposing factors related to these age groups.

- To study the different treatment modalities for a given type of cystic swelling of scrotum and their advantages and disadvantages.

- To study the postoperative complications of surgical procedures.

\section{Pathophysiology}

Tunica vaginalis testis is an invaginated serous sac and like any other serous cavity in the body it has a visceral and parietal layer. These two layers are separated by a potential cavity. The 
opposed surfaces are smooth and glistening. The cavity contains a thin layer of fluid to reduce friction.

The lining membrane is composed of a single layer of flattened endothelial cells supported by delicate areolar tissue. It forms a smooth glistening surface, opt to perform the function of preventing injury to the testis by constant rubbing with the medial aspect of the thigh. The fluid in the tunica vaginalis is kept in balance by the osmotic pressure, the colloid oncotic pressure of the blood. An increase in the intracapillary blood pressure or damage to the capillary endothelium increases the amount of fluid, which is of non-inflammatory origin and is called the transudate. ${ }^{5}$ Normally, fluid from the sac is drained by the lymphatics in the parietal layer of the sac, as there are no or few epididymis. Lymphatics in the parietal layer of the sac, as there are no or few lymphatics in the subserosa over the testis and any hindrance with this normal mechanism either in the form of increased production or decreased absorption leads to the formation of hydrocele. ${ }^{6}$

\section{MATERIALS AND METHODS}

This study was undertaken in the Chengalpattu Medical College and Hospital. The cases admitted to the surgical wards from April 2014 to April 2016 formed the material for this study. During this period, 100 cases admitted in various surgical units were studied in detail as per the proforma.

\section{Inclusion Criteria and Exclusion Criteria}

1. Cystic swelling arising from the testis and its coverings, epididymis and spermatic cord are included in this study.

2. In Exclusion criteria, the inguinoscrotal swellings and swellings from scrotal skin are excluded in this study.

\section{Methods}

Patients admitted with symptoms pertaining to the scrotal swelling were studied making use of the available facilities in the hospital.

\section{The Methods of Study consists of}

- Detail history taking.

- Clinical examination.

- Routine laboratory investigations.

- Relevant special investigations in some cases.

- Evaluation of preoperative status and appropriate preparation for surgery.

- $\quad$ Surgical treatment according to the merits of the case as decided by attending surgeon under suitable anaesthesia as decided by the anaesthesiologists.

- Operative findings.

- Post-operative course and management of post-operative complications.

- Fluid analysis and histopathological examination in relevant cases.

- Followup.

\section{RESULTS}

\section{Analysis of Data and Results}

\section{Observations and Discussion of Cases}

Present study includes 100 cases, cases admitted to Chengalpattu Medical College Hospital between April 2014 and 2016.
Age Incidence of Cystic Swellings of the Scrotum

\begin{tabular}{|c|c|c|c|}
\hline Sl. No. & Age Group & No. of Cases & Percentage \\
\hline 1 & $1-10$ & 12 & $12 \%$ \\
\hline 2 & $11-20$ & 20 & $20 \%$ \\
\hline 3 & $21-30$ & 17 & $17 \%$ \\
\hline 4 & $31-40$ & 22 & $22 \%$ \\
\hline 5 & $41-50$ & 9 & $9 \%$ \\
\hline 6 & $51-60$ & 10 & $10 \%$ \\
\hline 7 & $61-70$ & 9 & $9 \%$ \\
\hline 8 & $71-$ above & 1 & $1 \%$ \\
\hline \multicolumn{2}{|c|}{ Total } & 100 & \\
\hline \multicolumn{4}{|c|}{ Table 1. Age Incidence } \\
\hline
\end{tabular}

The youngest is $1 \frac{1}{2}$ years child and the oldest being 82 years. The maximum number of cases seen in the age group of 31 - 40 years, whereas minimum number of cases were seen after 70 years and above.

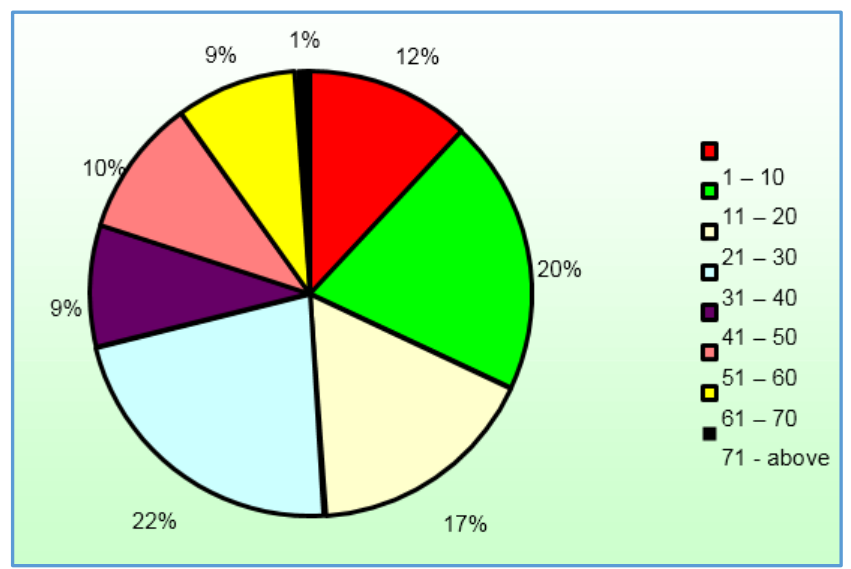

Chart 1. Age Incidence among Various Age Groups

Types of Occupation of Patients of Present Series

\begin{tabular}{|c|c|c|c|}
\hline Sl. No. & Occupation & No. of Cases & Percentage \\
\hline 1 & Coolie & 30 & $30 \%$ \\
\hline 2 & Business & 13 & $13 \%$ \\
\hline 3 & Agriculturists & 26 & $26 \%$ \\
\hline 4 & Student & 24 & $24 \%$ \\
\hline 5 & Others & 7 & $7 \%$ \\
\hline \multicolumn{2}{|r|}{ Total } & 100 & \\
\hline \multicolumn{4}{|c|}{ Table 2. Occupation of the Patients } \\
\hline
\end{tabular}

In this study, cystic swelling of the scrotum were more common in ryots followed by agriculturists and students. Most of them were from poor social-economic class.

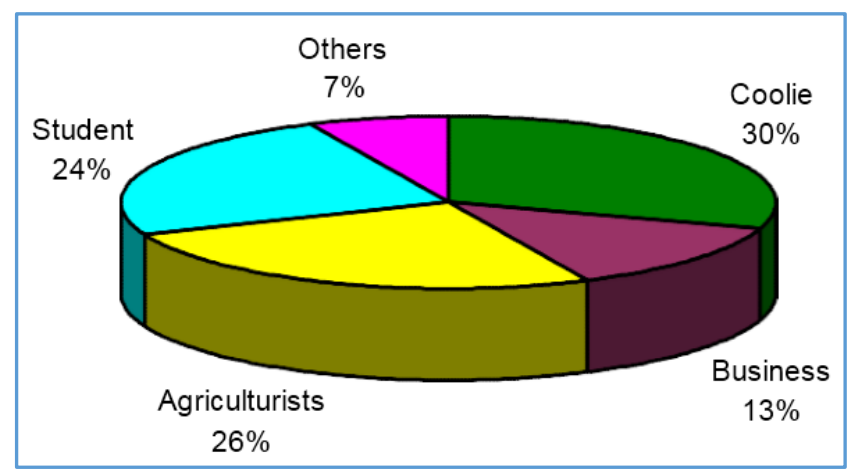

Chart 2. Occupation of the Patients 
Duration of Swelling

\begin{tabular}{|c|c|c|c|}
\hline Sl. No. & Duration & No. of Cases & Percentage \\
\hline 1 & $0-6$ months & 36 & $36 \%$ \\
\hline 2 & $6-12$ months & 41 & $41 \%$ \\
\hline 3 & $1-2$ years & 16 & $16 \%$ \\
\hline 4 & $2-3$ years & 1 & $16 \%$ \\
\hline 5 & $3-4$ years & 3 & $3 \%$ \\
\hline 6 & 4 years and above & 3 & $3 \%$ \\
\hline \multicolumn{3}{|c|}{ Total } & $\mathbf{1 0 0}$ \\
\hline \multicolumn{3}{|c|}{ Table 3. Duration of Swelling } \\
\hline
\end{tabular}

In this study in $41 \%$ of cases the duration of the swellings was 6 - 12 months followed by 0 to 6 months in $36 \%$ of cases, $16 \%$ of cases presented between 1 - 2 years, majority of the patients presented within 2 years of onset of symptoms.

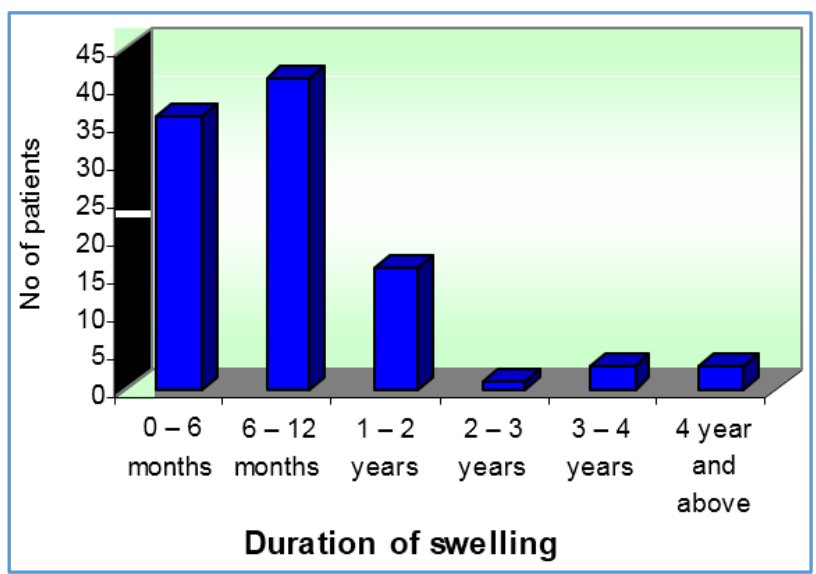

Chart 3. Duration of Swelling

The Distribution of Cystic Swellings in the Present Study

\begin{tabular}{|c|c|c|c|}
\hline Sl. No. & Side & No. of Cases & Percentage \\
\hline 1 & Right (R) & 54 & $54 \%$ \\
\hline 2 & Left (L) & 37 & $37 \%$ \\
\hline 3 & Bilateral (B/l) & 9 & $9 \%$ \\
\hline \multicolumn{2}{|r|}{ Total } & 100 & \\
\hline \multicolumn{4}{|c|}{ Table 4. Sidewise Distribution of Cystic Swellings } \\
\hline
\end{tabular}

Sidewise distribution of the swelling showed a higher incidence on the right side of the scrotum $54 \%$, when compared with the left side of the scrotum $37 \%$; bilateral swelling were present in $9 \%$ of the cases.

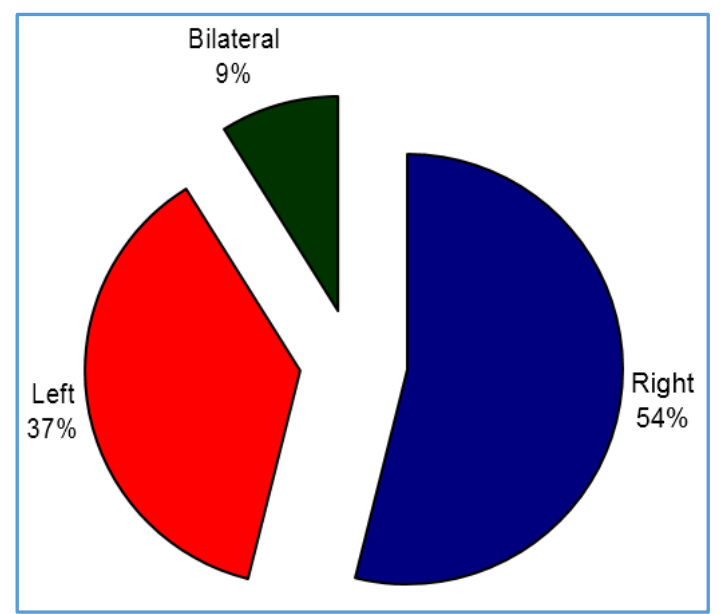

Chart 4. Sidewise Distribution of Cystic Swelling The Type of Lesions in the Present Study

\begin{tabular}{|c|c|c|c|}
\hline Sl. No. & Lesion & No. of Cases & Percentage \\
\hline 1 & $\begin{array}{c}\text { Primary Vaginal } \\
\text { Hydrocele }\end{array}$ & 57 & $57 \%$ \\
\hline 2 & $\begin{array}{c}\text { Congenital } \\
\text { Hydrocele }\end{array}$ & 14 & $14 \%$ \\
\hline 3 & Epididymal Cyst & 11 & $11 \%$ \\
\hline 4 & $\begin{array}{c}\text { Encysted } \\
\text { Hydrocele of Cord }\end{array}$ & 7 & $7 \%$ \\
\hline 5 & $\begin{array}{c}\text { Secondary } \\
\text { Hydrocele }\end{array}$ & 2 & $2 \%$ \\
\hline 6 & Haematocele & 3 & $3 \%$ \\
\hline 7 & Pyocele & 4 & $4 \%$ \\
\hline 8 & Spermatocele & 2 & $2 \%$ \\
\hline \multicolumn{3}{|c|}{ Total } & 100 \\
\hline \multicolumn{3}{|c|}{ Table 5. Type of Lesions } \\
\hline
\end{tabular}

In our study of cystic swelling of scrotum, the commonest presentation was primary vaginal hydrocele (57\%) followed by congenital hydrocele (14\%) and epididymal cyst $11 \%$ and least was spermatocele and secondary hydrocele with $2 \%$ each.

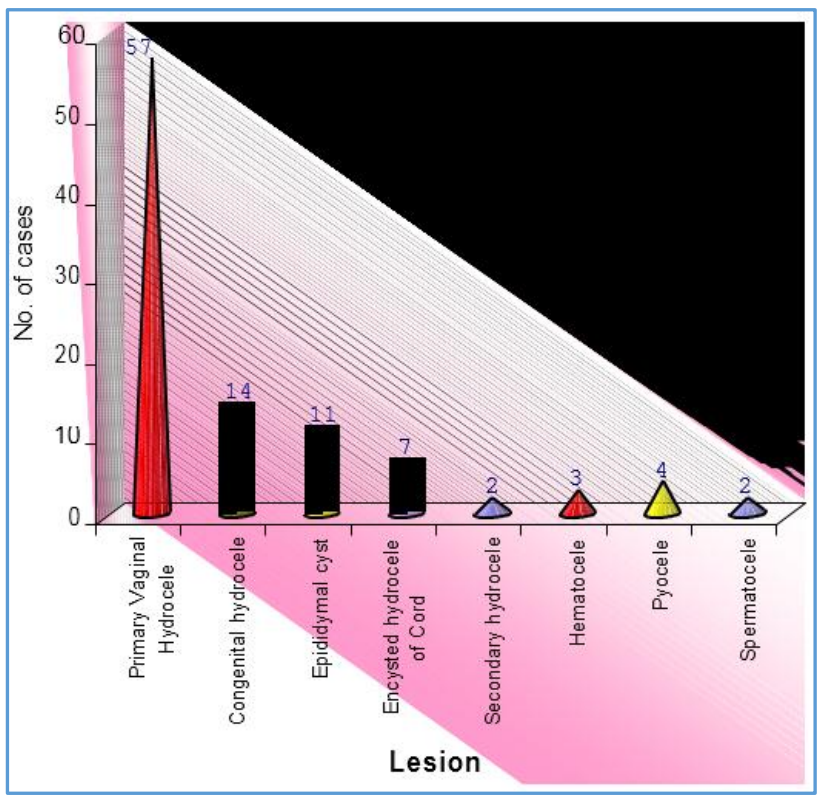

Chart 5. Types of Lesion

Type of Anaesthesia used in the Present Study

\begin{tabular}{|c|c|c|c|}
\hline Sl. No. & Anaesthesia & No. of Cases & Percentage \\
\hline 1 & Spinal & 85 & $85 \%$ \\
\hline 2 & General & 13 & $13 \%$ \\
\hline 3 & Local & 2 & $2 \%$ \\
\hline \multicolumn{2}{|r|}{ Total } & 100 & \\
\hline & Table 6. & of Anaesthe & \\
\hline
\end{tabular}

$85 \%$ of patients were given spinal anaesthesia followed by $13 \%$ of patients with general anaesthesia and $2 \%$ of patients with local anaesthesia. 


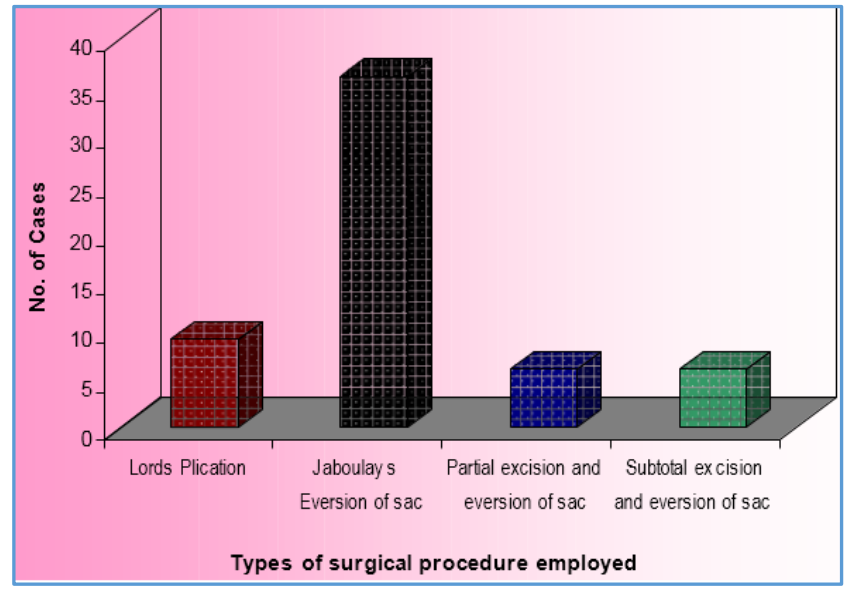

Chart 8. Types of Surgical Procedures Employed

Post-Operative Complications

Post-Operative Complications Noticed in the Present Study

\begin{tabular}{|c|c|c|c|c|c|}
\hline $\begin{array}{c}\text { Sl. } \\
\text { No. }\end{array}$ & Operation & $\begin{array}{c}\text { No. of } \\
\text { Cases }\end{array}$ & $\begin{array}{c}\text { Scrotal } \\
\text { Oedema }\end{array}$ & $\begin{array}{c}\text { Haematom } \\
\text { a }\end{array}$ & $\begin{array}{c}\text { Wound } \\
\text { infection }\end{array}$ \\
\hline 1 & $\begin{array}{c}\text { Jaboulay's } \\
\text { eversion }\end{array}$ & 36 & 10 & 12 & 5 \\
\hline
\end{tabular}

\begin{tabular}{|c|c|c|c|c|c|}
\hline 2 & $\begin{array}{c}\text { Subtotal } \\
\text { excision and } \\
\text { eversion of sac }\end{array}$ & 6 & 2 & 2 & 2 \\
\hline 3 & $\begin{array}{c}\text { Partial excision } \\
\text { and eversion } \\
\text { of sac }\end{array}$ & 6 & 2 & 1 & 2 \\
\hline 4 & Lord's plication & 9 & - & - & - \\
\hline 5 & \begin{tabular}{|c} 
Excision for \\
epididymal cyst \\
and \\
encysted \\
hydrocele of \\
cord \\
+ spermatocele
\end{tabular} & 20 & 4 & 1 & 2 \\
\hline 6 & Herniotomy & 14 & 2 & - & - \\
\hline 7 & $\begin{array}{c}\text { Incision and } \\
\text { drainage }\end{array}$ & 4 & - & - & - \\
\hline 8 & $\begin{array}{l}\text { Evacuation of } \\
\text { clot and } \\
\text { eversion of sac }\end{array}$ & 3 & - & - & - \\
\hline 9 & $\begin{array}{c}\text { Subtotal } \\
\text { excision in } \\
\text { secondary } \\
\text { hydrocele }\end{array}$ & 2 & 2 & - & - \\
\hline & Total & 100 & 20 & 16 & 11 \\
\hline
\end{tabular}

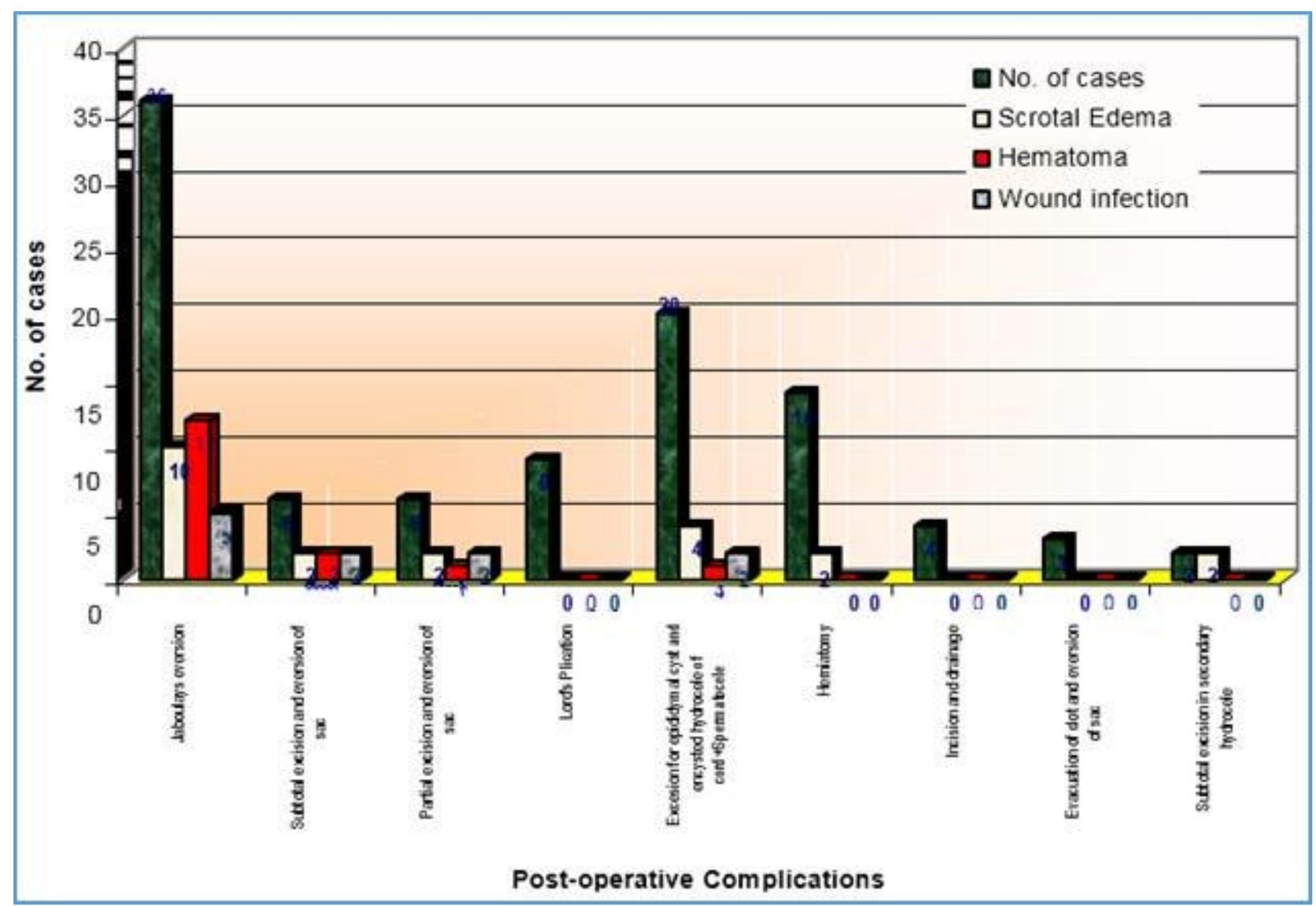

Per-Operative Findings of Testis

Chart 9. Post-Operative Complications

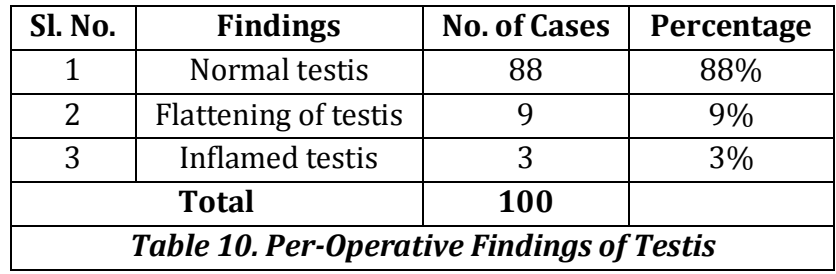

Per-operatively, normal testis was observed in 88 cases; 9 cases showed flattening of testis in primary vaginal hydrocele. Inflamed testis was seen in $3 \%$ of cases. 


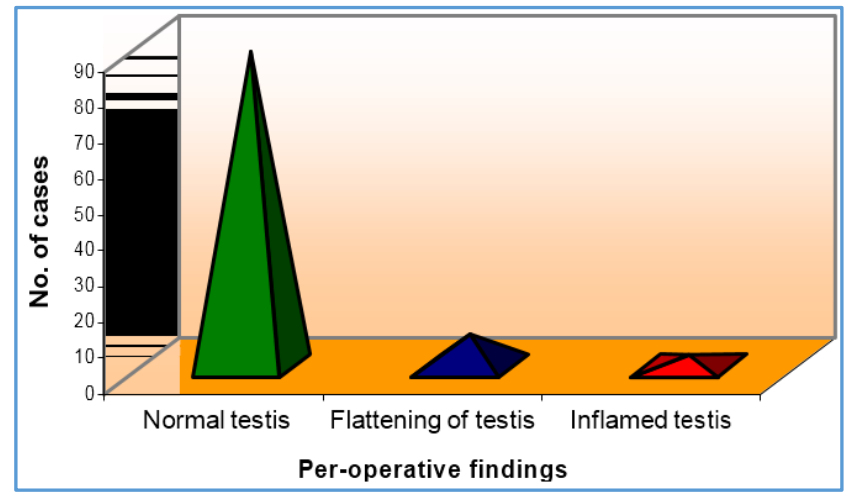

Chart 10. Per-Operative Findings

\section{DISCUSSION}

Study of 100 cases of cystic swelling of scrotum was done between April 2014 and April 2016 over a span of 48 months in Chengalpattu Medical College, Tamilnadu. The study was compared with other studies.

Cystic swellings of the scrotum occur in all the age groups, but in present study of 100 cases most of the patients were in the 31 - 40 years' age group (22\%) followed by $11-20$ years of age group (20\%), most of them presented with scrotal swelling with pain.

Clinical examination was found to be very important for diagnosis.7 Majority of the swelling were cystic in consistency, fluctuant and translucent and transillumination was negative in cases of secondary hydrocele, spermatocele, haematocele, pyocele and because of the opaque nature of their contents. The diagnosis confirmed by scrotal ultrasonography. ${ }^{8}$
The commonest cause for cystic swelling for the scrotum was primary vaginal hydrocele, ${ }^{9}$ which accounts for $57 \%$. The other causes were epididymal cyst $11 \%$, congenital hydrocele $14 \%$, encysted hydrocele of cord $7 \%$, secondary hydrocele $2 \%$, haematocele $3 \%$, pyocele $4 \%$ and spermatocele $2 \%$.

Maximum number of cystic swelling of scrotum were seen in the age group of 31 - 40 years, i.e. $22 \%$.

The incidence of hydrocele was more common on the right side of the scrotum when compared to the left side.

A similar incidence was observed in a study done by C. Mahalingam (1985).

While no cause could be detected for primary vaginal hydrocele and epididymal cyst, secondary hydrocele was due to disease of the testis and epididymitis of the 2 cases of secondary hydrocele, both were secondary to tuberculous epididymo-orchitis. The cause for haematocele was recent trauma in 2 cases and in one case it was post-hernioplasty operation and for pyocele was infection of hydrocele.

Surgery was gold standard and was employed in all the cases.

Spinal anaesthesia was used in most of the cases i.e. 85\%, general anaesthesia in $13 \%$ and local anaesthesia in $2 \%$ as per the merit of the patient. ${ }^{10}$

In primary vaginal hydrocele Lord's plication was found to be simple, effective and associated with least post-operative complications. The other conventional techniques like partial/sub-total excision and eversion of sac and eversion of sac were associated with increased incidence of complications like haematoma, scrotal oedema and infection. The results of present study are comparable to that of the previous series.

\begin{tabular}{|c|c|c|c|c|c|c|c|}
\hline \multirow{2}{*}{ Sl. No. } & \multirow{2}{*}{ Author } & \multirow{2}{*}{ Year } & \multirow{2}{*}{ Journal } & \multicolumn{2}{c|}{ Lord's Plication Procedure } & \multicolumn{2}{c|}{ Excision/Eversion of Sac } \\
\cline { 4 - 8 } & & & No. of Cases & Haematoma & No. of Cases & Haematoma \\
\hline 1 & Effron et al & 1967 & SGO & 29 & 1 & 30 & $9(30 \%)$ \\
\hline 2 & Dah et al & 1972 & Arch Surgery & 25 & 1 & 23 & $6(26 \%)$ \\
\hline 3 & Reddy et al & 1972 & IJS & 400 & Negligible & - & - \\
\hline 4 & Rai et al & 1978 & IJS & 50 & - & 20 & $15(75 \%)$ \\
\hline 5 & Lord's & 1964 & BJS & 22 & - & - & - \\
\hline 6 & Campbell & 1927 & SGO & - & - & 502 & $12(24 \%)$ \\
\hline 7 & Present series & $2004-2006$ & - & 9 & - & 48 & $15(31.6 \%)$ \\
\hline \multicolumn{7}{|c|}{ Table 11. Comparison with the Previous Series 1 } \\
\hline
\end{tabular}

\begin{tabular}{|c|c|c|c|c|c|c|c|}
\hline \multirow{2}{*}{ Sl. No. } & \multirow{2}{*}{ Series } & \multicolumn{3}{|c|}{ Lord's Plication Procedure } & \multicolumn{3}{c|}{ Excision/Eversion of Sac } \\
\cline { 3 - 8 } & & No. of Cases & Haematoma & Infection & No. of Cases & Haematoma & Infection \\
\hline 1 & Agarwal Series & 50 & - & - & 50 & $14(28 \%)$ & $8(16 \%)$ \\
\hline 2 & Present Study & 9 & - & - & 48 & $15(31.6 \%)$ & $9(18.7 \%)$ \\
\hline \multicolumn{4}{|c|}{ Table 12. Comparative Studies (Agarwal Series) } \\
\hline
\end{tabular}

The results of this study are comparable to that of previous series. Of the nine cases of hydrocele treated by Lord's plication, none developed haematoma. Haematoma was observed in 15 cases out of 48 cases treated by partial/subtotal excision and eversion/eversion of sac. This is high compared to Campbell series, low compared to Rai et al series, but comparable to Effron et al and Dahl et al series.

Lord's plication gave rise to less complications and postoperative morbidity. May be because Lord's plication procedure avoids the opening of the cleavage between the sac and surrounding tissue, thus reducing the oozing and subsequent haematoma formation. 11

O. P. Agarwal in 1983 did a comparative study on radical cure of hydrocele.

In this study he showed that among 50 cases who were operated by Lord's plication, none of them developed haematoma or infection, whereas in 50 cases who underwent eversion of sac $14(28 \%)$ cases developed haematoma and 8 $(16 \%)$ cases developed infection. In our study, among 48 cases underwent eversion of sac only 15 (31.6\%) developed haematoma and $9(18.7 \%)$ cases developed infection. 
This study shows that Lord's plication for hydrocele is simple, effective, safe and economical. It is the procedure of choice for management of small-to-moderate sized primary hydrocele. The only factor against this procedure is a large hydrocele or a thick walled hydrocele where eversion subtotal excision of sac is the operation of choice.12 The common postoperative complications observed were pain, scrotal oedema and haematoma, managed conservatively by analgesics, scrotal support and antibiotics.

Minimal tissue dissection and with maintaining haemostasis during surgery are important for prevention of post-operative complications. Post-operative scrotal support helps to relieve pain, minimise scrotal oedema and prevent haematoma.

\section{Discharge and Followup}

While discharging each patient was educated about the disease and the study; and was requested to attend the outpatient department for followup.

Followup was done for 2 - 4 months. In general it was poor, may be due to their work at fields or for daily earnings. Cases which were followed regularly showed no recurrence.

Most of our patients were discharged between 5 - 7 days, but some patients who developed scrotal oedema and infection were kept till 10 days.

Earliest patients discharged was on 3rd post-operative day after herniotomy.

The result of present study are comparable to that of the previous series.

\begin{tabular}{|c|c|c|c|c|}
\hline $\begin{array}{c}\text { Sl. } \\
\text { No. }\end{array}$ & Author & Year & $\begin{array}{c}\text { No. of } \\
\text { Cases }\end{array}$ & $\begin{array}{c}\text { Post- } \\
\text { Operative } \\
\text { Stay }\end{array}$ \\
\hline 1 & Efforn et al & 1967 & 29 & 5 \\
\hline 2 & Reddy et al & 1973 & 400 & $5-6$ \\
\hline 3 & Rai et al & 1978 & 50 & $3-8$ \\
\hline 4 & Present study & $2004-2006$ & 100 & $5-7$ \\
\hline \multicolumn{3}{|c|}{ Table 13. Comparison of Results of Various Studies } \\
\hline
\end{tabular}

\section{CONCLUSION}

Majority of the patients with cystic swelling of the scrotum belonged to the 31 - 40 years of age group $22 \%$ followed by 11 - 20 years of age group 20\%. Primary vaginal hydrocele is the commonest cause of cystic swelling of the scrotum with 57\%. The most common presenting feature is asymptomatic swelling of the scrotum. The exact cause of primary vaginal hydrocele is not known. Secondary hydrocele is due to some underlying disease of the testis and epididymis. Big primary vaginal hydrocele of long duration can produce pressure effects on the testis. Surgical treatment is the gold standard for management of cystic swelling of the scrotum. Lord's plication for hydrocele is simple, effective, safe and economical; proper preoperative preparation of scrotum and surrounding area and with good personal hygiene. Most of the post-operative infections could be controlled. Minimal tissue handling and good haemostatic control are the key to prevention of postoperative complications. Hydrocele in infants is practically always congenital and associated with hernia. Maximum number of cases were ryots in occupation followed by Agriculturists and students respectively. Most of them were from poor socioeconomic class. Cystic swelling of scrotum was most common on right side of scrotum.

Haematomas were very common in postoperative period; i.e. after subtotal/partial excision of sac in hydrocele, no haematoma in Lord's procedure. Followup was generally poor in this study; most of them followed up till 2 months; only few followed up till 4 months. No recurrence was observed in these cases.

\section{REFERENCES}

1. Fowler C. The testis and scrotum. Chapter No: 68. In: Russel RCG. Bailey and loves short practice of surgery. 23rd edn. London: Arnold Publishers 2000:1270-80.

2. Goldstin M. Surgical management of male infertility and other scrotal disorders. In: Walsh PC, Retik AB, Vaughan ED, et al. $7^{\text {th }}$ edn. Wein campbells urology. WB Saunders Company 1998;2:1332-74.

3. Johstone JMS. Hargreave TB. Male urethra and genital organs. In: Rintoul RF. $8^{\text {th }}$ edn. Farquharsons text book of operative surgery. Churchill Living stone 1995:672-83.

4. Rodriguez WC, Rodriguez DD, Fortuno RF. The operative treatment of hydrocele: a comparison of 4 basic techniques. Journal of Urology 1981;125(6): 804-5.

5. Russel RCG, Williams NS, Bulstrode CJK. Bailey and love short practice of surgery. 24th edn. Arnolds publications 2004:1403-16.

6. Wenerth JL, Robertson GN. The male genital system. In: Sabastian DC, Lyerly HK. Sabastion textbook of surgerythe biological basis of morden surgical practice. $15^{\text {th }}$ edn. WB Saunders company 1997:1556-62.

7. Testis DS. Epididymis \& scrotum. Chapter 60. In: Concise text book of surgery. Das, Calcutta 1994:p 1266.

8. Bernd H, Fobbe F, Loy V, et al. Testicular cysts: differentiation with US and clinical findings. Radiology 1988;168(1):19-23.

9. Ozdilek S. The pathogenisis of idiopathic hydrocele and a simple operative technique. Journal of urology 1957;77(2):282-4.

10. Wilkinson JI. An operation for large scrotal hydrocele. British journal of surgery 1973;60(6):450-2.

11. Jawer PK, Sharma LS. Surgery of hydrocele. Indian journal of surgery 1979:700-4.

12. Sharlip, Ira D. Surgery of scrotal concerns. Urology clinics of North America 1987:145-8. 